\title{
DAMPAK DARI EVENT SAIL BANDA 2010 TERHADAP PERKEMBANGAN WILAYAH KECAMATAN BANDA
}

\section{THE IMPACT OF THE 2010 SAIL BANDA EVENT ON THE DEVELOPMENT OF BANDA DISTRICT}

\author{
Muhammad Ilham Ryansyah Ambona, M Sani Roychansyah ${ }^{b}$, Yori Herwangic \\ aUniversitas Gadjah Mada; Jl. Grafika No. 2 , Kampus UGM, Daerah Istimewa Yogyakarta 55281; ryanambon@ymail.com \\ b Universitas Gadjah Mada; Jl. Grafika No. 2 , Kampus UGM, Daerah Istimewa Yogyakarta 55281; saniroy@gmail.com \\ cUniversitas Gadjah Mada; Jl. Grafika No. 2 , Kampus UGM, Daerah Istimewa Yogyakarta 55281; yherwangi@ugm.ac.id
}

Info Artikel:

- Artikel Masuk: 21 November 2018 - Artikel diterima: 13 Desember 2018 - Tersedia Online: 24 Mei 2019

\section{ABSTRAK (dalam Bahasa Indonesia)}

Salah satu sektor pendapatan daerah dari Provinsi Maluku yang utama berasal dari sektor pariwisata. Sebagai salah satu sektor utama untuk menghasilkan pendapatan daerah, sektor pariwisata harus lebih dikembangkan agar hasil yang didapat juga bisa dirasakan secara lebih optimal bagi pemerintah dan juga masyarakat. Salah satu upaya yang dilakukan oleh Pemerintah Pusat dan Pemerintah Daerah Provinsi Maluku untuk mengembangkan sektor pariwisata adalah melalui penyelenggaraan event pariwisata tingkat internasional yaitu Event Sail Banda yang dilaksanakan di Kecamatan Banda, Kabupaten Maluku Tengah, Provinsi Maluku. Penelitian ini bertujuan untuk mengevaluasi sejauh mana capaian perkembangan wilayah Kecamatan Banda pasca penyelenggaraan Event Sail Banda serta dampak apa saja yang dihasilkan terhadap perkembangan wilayah Kecamatan Banda. Hal ini dikarenakan walaupun sudah dilaksanakan Event Sail Banda tetapi diduga tidak terdapat dampak dari penyelenggaraan event tersebut terhadap peningkatan pendapatan dan kesehjateraan masyarakat lokal di Kecamatan Banda. Dalam penelitian ini, pendekatan yang digunakan adalah pendekatan deduktif kualitatif dengan menggunakan analisis capaian perkembangan wilayah. Hasil dari analisis tersebut akan digunakan untuk melihat dampak dari penyelenggaraan Event Sail Banda. Temuan pada penelitian ini adalah dapat disimpulkan bahwa penyelenggaraan Event Sail Banda di Kecamatan Banda tidak memberikan dampak yang signifikan terhadap peningkatan pendapatan dan kesehjahteraan masyarakat. Dari keempat tujuan penyelenggaraan Event Sail Banda hanya satu tujuan yang tercapai yaitu meningkatkan kunjungan wisatawan.

Kata Kunci : perkembangan wilayah; pariwisata; event; dampak

\section{ABSTRACT}

One of the main regional income sectors of Maluku Province comes from the tourism sector. As one of the main sectors to generate regional income, the tourism sector must be further developed so that the results can also be felt more optimally for the government and the community. One of the efforts carried out by the Central Government and the Regional Government of Maluku Province to develop the tourism sector is through organizing an international level tourism event, namely Sail Banda Event held in Banda District, Central Maluku Regency, Maluku Province. This study aims to evaluate the extent to which the development of the Banda Subdistrict area after the implementation of the Sail Banda Event and the impacts that have been made on the development of the Banda Subdistrict area. This is because even though the Sail Banda Event has been carried out but it is suspected that there was no impact from the holding of the event to increase the income and health of the local community in Banda District. In this study, the approach used is a qualitative deductive approach using analysis of regional development achievements. The results of this analyzes will be used to see the impact of organizing the Sail Banda Event. The findings of this study are that the implementation of the Sail Banda Event in Banda District does not have a significant impact on increasing the income and welfare of the community. Of the four objectives of organizing the Banda Sail Event, only one goal was achieved, namely increasing tourist visits.

Keyword: regional evelopment; tourism; event; impact 
Ambon, Royachansyah, Herwangi / Jurnal Pembangunan Wilayah dan Kota, Vol 15, No 1, 2019, 20-32

Doi: $10.14710 /$ pwk.v15i1.21008

\section{PENDAHULUAN}

Indonesia merupakan negara kepulauan yang terbesar di dunia dan memiliki potensi wisata bahari dengan pemandangan bawah lautnya yang luar biasa salah satunya adalah Provinsi Maluku. Salah satu upaya yang dilakukan oleh Pemerintah Pusat dan Pemerintah Daerah Provinsi Maluku untuk mengembangankan Pariwisata di Provinsi Maluku adalah melalui penyelenggaraan event pariwisata tingkat internasional yaitu Event Sail Banda yang merupakan bagian dari Even Sail Indonesia. Event Sail Banda memiliki tujuan yaitu menumbuhkan pusat - pusat perekonomian baru di destinasi sail; meningkatkan kunjungan wisatawan ke lokasi penyelenggaraan sail; meningkatkan keterpaduan dan sinergi program dan anggran lintas kementrian/lembaga pusat dan daerah, serta partisipasi swasta dalam pembangunan kesehjateraan rakyat berkelanjutan; dan meningkatkan kualitas dan kuantitas infrastruktur serta fasilitas umum lainnya bagi lokasi penyelenggaraan sail. Semenjak 8 tahun pelaksaan Event Sail Banda terdapat beberapa dampak diduga sudah dirasakan oleh masyarakat lokal Kecamatan Banda sesuai dengan tujuan penyelenggaraan Event Sail Banda yaitu adanya pengembangan dan perbaikan infrastruktur dan peningkatan kunjungan wisatawan domestik maupun mancanegara tetapi untuk kedua tujuan lainnya yaitu menumbuhkan pusat - pusat perekonomian baru di destinasi sail dan meningkatkan keterpaduan dan sinergi program dan anggran lintas kementrian/lembaga pusat dan daerah, serta partisipasi swasta dalam pembangunan kesehjateraan rakyat berkelanjutan diduga belum tercapai.

Menurut Allen dkk (2011) alasan utama dari pelaksanaan suatu event adalah untuk mendapatkan keuntungan ekonomi yang diperoleh dari pelaksanaan event tersebut. Event dapat berdampak pada daerah yang menyelenggarakan melalui berbagai cara, misalnya melalui pendapatan devisa, pendapatan, dan penciptaan lapangan pekerjaan. Dampak besar lainnya yang disebabkan oleh event pada daerah yang menyelenggarakan adalah membuat kesempatan untuk membuka usaha yang lebih besar. Event adalah cara bagi daerah yang menyelenggarakan untuk menunjukan keahlian masyarakat lokal, mengundang investor yang potensial, dan mempormosikan kesempatan usaha yang baru. Kemudian menurut Kreag (2001) penyelenggaraan event juga sering memicu pengembangan utilitas publik seperti air, pembuangan air limbah, pedestrian, pencahayaan, listrik, persampahan, dan lansekap yang semuanya dapat menguntungkan masyarakat lokal dan turis. Kreag juga menambahkan, event juga dapat memicu pengembangan infrastruktur transportasi seperti jalan yang diperbaharui, bandara, dan transportasi publik.

Pada penelitian sebelumnya oleh Tanasale (2013) menyatakan bahwa event dapat menjadi alat untuk penyelesaian sebuah konflik karena memiliki dampak yang positif. Kemudian penelitian dari Lill (2015) juga menyatakan bahwa event berdampak positif terhadap kehidupan sosial budaya dan ekonomi seperti meningkatnya pendapatan masyarakat setempat serta menciptakan lapangan kerja baru. Selanjutnya menurut hasil penelitian dari Etiosa (2012), menyelenggarakan suatu event dapat berdampak terhadap secara sosial budaya, lingkugan, ekonomi, dan politik bagi daerah yang menyelenggarakan. Yang membedakan penelitian ini dengan ketiga penelitian diatas adalah, hasil dari ketiga penelitian sebelumnya tersebut selalu menunjukan bahwa dengan adanya penyelenggaraan suatu event dapat berdampak positif terhadap daerah yang menyelenggarakan event tersebut baik dari segi infrastruktur, sosial, dan ekonomi. Namun diduga bahwa dampak positif yang didapatkan dari penyelenggaraan event tersebut tidak terjadi selama penyelenggaraan Event Sail Banda 2010 yang dilaksanakan di Kecamatan Banda. Oleh karena itu, penelitian ini bertujuan untuk mengevaluasi sejauh mana capaian perkembangan wilayah Kecamatan Banda setelah penyelenggaraan Event Sail Banda 2010 serta dampak apa saja yang dihasilkan. Dalam penelitian ini, pendekatan yang digunakan adalah pendekatan deduktif kualitatif dengan menggunakan analisis capaian perkembangan wilayah. Dari penelitian ini diharapkan dapat memberikan manfaat dalam hal menambah pemahaman lebih mengenai pengaruh dari suatu event pariwisata terhadap perkembangan dari suatu wilayah. Dengan adanya penelitian ini diharapkan juga dapat menjawab pertanyaan - pertanyaan penelitian sebelumnya mengenai event pariwisata sebagai pendorong perkembangan suatu wilayah yang belum bisa terjawab. 


\section{DATA DAN METODE}

\subsection{Event Sail Banda}

Dalam penyelenggaraan Event Sail Banda yang dilaksanakan dari tanggal 27 juli sampai dengan 8 agustus, Kecamatan Banda di Kabupaten Maluku Tengah menjadi salah satu tempat penyelenggara Event Sail Banda bersama dengan Kota Ambon. Kegiatan yang dilaksanakan di Kecamatan Banda yang berlangsung selama 3 hari dari tanggal 27 - 29 juli berupa festival budaya, lomba diving, lomba mancing, serta kegiatan agrowisata perkebunan pala khas banda. Kecamatan Banda secara administratif berada di Kabupaten Maluku Tengah, Provinsi Maluku. Kepulauan Banda terletak di tengah-tengah laut Banda (Banda Sea) dan sebagian besar wilayahnya merupakan perairan. Kecamatan Banda terdiri dari 13 pulau dengan 7 pulau dihuni dan 6 pulau tidak dihuni serta memiliki wilayah seluas kurang lebih $172 \mathrm{~km}^{2}$. Banda Neira merupakan Ibukota Kecamatan Banda yang secara geografis terletak pada koordinat $5^{\circ} 43^{\prime}-6^{\circ} 316^{\prime}$ LS dan $129^{\circ} 44^{\prime}-130^{\circ} 04^{\prime}$ BT. Batas-batas administrasi wilayahnya adalah :

- Sebelah Utara dengan Selat Seram;

- Sebelah Timur dengan Perairan Laut Banda;

- Sebelah Selatan dengan Kepulauan Teon Nila Serua; dan

- Sebelah Barat dengan Perairan Laut Banda.

Kecamatan Banda terbagi menjadi 18 desa (disebut Negeri). Desa Selamon merupakan desa yang terluas di Kecamatan Banda yaitu sebesar 48,23 km² atau 16,24\% luas keseluruhan. Sedangkan desa terkecil adalah Desa Dwiwarna yaitu sebesar $1,40 \mathrm{~km}^{2}$ atau $0,81 \%$ luas keseluruhan. Berikut adalah gambar peta dari Kecamatan Banda.

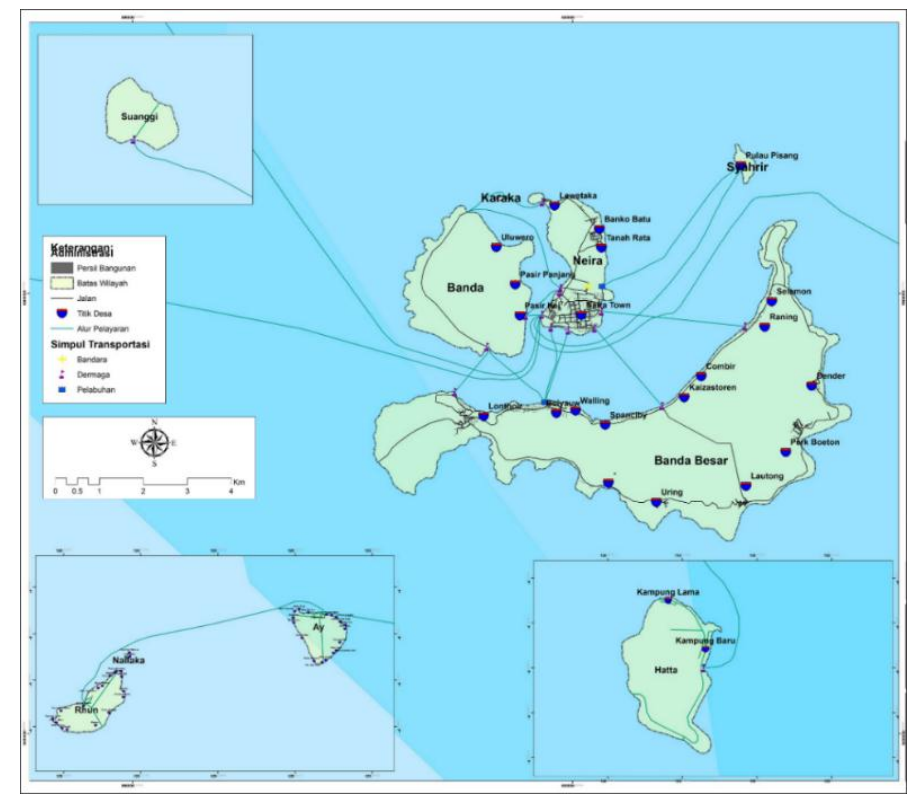

Gambar 1. Peta Kecamatan Banda (Laporan Rencana Induk dan Rencana Detail Kawasan Strategis Pariwisata Nasional Wilayah Kepulauan Banda dan Sekitarnya, 2016)

Event Sail Banda merupakan event pariwisata tingkat internasional. Event yang sekaligus menjadi ajang promosi Kecamatan Banda di tingkat nasional maupun internasional tersebut harus dapat diselenggarakan dengan seksama sehingga tujuan dari penyelengaran event itu sendiri dapat tercapai. 
Untuk dapat mensukseskan Event Sail Banda tersebut, tentunya diperlukan persiapan yang matang dan kerjasama dari semua pihak baik dari pemerintahan, swasta, hinga masyarakat setempat. Oleh karena itu terdapat beberapa kegiatan yang diduga dilaksanakan untuk menyambut Event Sail Banda. Adapun kegiatan - kegiatan yang diduga dilaksanakan dalam persiapan penyelenggaraan Event Sail Banda adalah :

1. Mensosialisasikan dan mempersiapkan masyarakat Kecamatan Banda guna menyambut penyelenggraan Event Sail Banda

2. Melakukan beberapa perbaikan infrastruktur seperti jalan, bandara, serta pelabuhan

3. Meningkatkan pelayanan transportasi dari dan menuju Kecamatan Banda, serta di dalam Kecamatan Banda sendiri

4. Melakukan beberapa peningkatan dan perbaikan prasarana

5. Melakukan perbaikan dan peremajaan berbagai wisata budaya dan wisata sejarah yang ada di Kecamatan Banda

6. Mengadakan pembersihan lingkungan di lokasi - lokasi wisata alam

7. Membangun fasilitas - fasilitas penunjang pariwisata seperti penginapan dan rumah makan

Berdasarkan laporan Event Sail Banda 2010 dari Dinas Infokom Provinsi Maluku, intensitas atau pengeluaran setiap kegiatan dan sumberdaya dalam rangka persiapan penyelenggaraan Event Sail Banda diatas, total anggaran yang dipersiapkan untuk penyelenggaraan program Event Sail Banda di Kecamatan Banda sebesar Rp 43.691.354.250,00 dengan rincian sebagai berikut.

1. Anggaran Fisik

Bidang Kebudayaan dan Pariwisata $=\mathrm{Rp} 6.800 .000 .000,00$

Bidang Pekerjaan Umum $\quad=$ Rp $11.800 .000 .000,00$

Bidang Perhubungan $\quad=$ Rp 12.966.000.000,00

Bidang Kelistrikan PLN $\quad=$ Rp 4.159.179.250,00

Bidang Kominfo

Bidang Kesehatan

Total

$=\operatorname{Rp} 2.000 .000 .000,00$

$=\operatorname{Rp} 3.514 .600 .000,00+$

$=\operatorname{Rp} 41.239 \cdot 779 \cdot 250,00$

2. Anggaran Non Fisik

Acara Lokal dan Publikasi

Kegiatan Utama

Total

$$
\begin{aligned}
& =\operatorname{Rp} 1.400 .000 .000,00 \\
& =\operatorname{Rp} 1.051 .575 .000,00+ \\
& =\operatorname{Rp} 2.451 .575 .000,00
\end{aligned}
$$

2.2. Metode

Dalam penelitian ini analisis capaian perkembangan wilayah digunakan untuk mengevaluasi seberapa jauh capaian perkembangan wilayah yang dilakukan di Kecamatan Banda pasca penyelenggaraan Event Sail Banda. Evaluasi terhadap perkembangan wilayah di Kecamatan Banda menggunakan KKL atau kerangka kerja logis. Analisis ini dimulai dari input kegiatan dan berbagai sumberdaya yang didalamnya terdapat kegiatan - kegiatan yang dilaksanakan serta rincian biaya yang dipergunakan dalam persiapan proyek. Kemudian kegiatan - kegiatan serta biaya tersebut diverifikasi menggunakan alat verifikasi yang ditentukan. Input kegiatan dan berbagai sumber daya yang dilaksanakan dapat menghasilkan output apabila beberapa asumsinya terpenuhi. Kemudian setelah output kegiatan terpenuhi, output tersebut diverifikasi dengan alat verifikasi yang ditentukan. Kemudian apabila output tersebut sesuai dengan asumsi, maka secara langsung dikategorikan dapat memenuhi tujuan proyek. Selanjutnya, tujuan proyek yang telah terpenuhi tersebut kemudian dilanjutkan tahapan verifikasinya apakah menghasilkan tujuan lebih besar yang pencapaiannya disumbangkan oleh proyek yang dievaluasi atau tidak. Apabila tujuan lebih besar yang pencapaiannya disumbangkan oleh proyek dapat terpenuhi berarti dapat dikatakan bahwa proyek tersebut berhasil memberikan dampak. Pada kerangka kerja logis yang digunakan untuk mengevaluasi, bagian outcome atau 
tujuan menggunakan tujuan dari penyelenggaraan Event Sail Banda yaitu menumbuhkan pusat - pusat perekonomian baru; meningkatkan kunjungan wisatawan; meningkatkan partisipasi swasta dalam pembangunan kesehjateraan rakyat berkelanjutan; serta meningkatkan kualitas dan kuantitas infrastruktur serta fasilitas umum lainnya. Untuk lebih jelasnya dapat dilihat pada tabel kerangka kerja logis berikut.

Table 1. Kerangka Kerja Logis (Hasil Olahan Pribadi, 2018)

\begin{tabular}{llll}
\hline \multicolumn{1}{c}{ Ringkasan Naratif } & \multicolumn{1}{c}{ Indikator Objektif } & \multicolumn{1}{c}{ Alat Verifikasi } & \multicolumn{1}{c}{ Asumsi Penting } \\
\hline $\begin{array}{l}\text { Tujuan lebih besar yang } \\
\text { pencapaiannya akan } \\
\text { disumbang oleh proyek }\end{array}$ & \multicolumn{1}{c}{$\begin{array}{l}\text { Untuk mengukur } \\
\text { ketercapaian dari } \\
\text { tujuan yang lebih besar }\end{array}$} & $\begin{array}{l}\text { Asumsi tentang nilai } \\
\text { jangka panjang proyek }\end{array}$ \\
\hline Tujuan Proyek : & $\begin{array}{l}\text { Kondisi yang mencerminkan } \\
\text { tercapainya tujuan proyek : }\end{array}$ & $\begin{array}{l}\text { Untuk mengukur } \\
\text { ketercapaian dari } \\
\text { tujuan proyek }\end{array}$ & $\begin{array}{l}\text { Asumsi hubungan antara } \\
\text { tujuan proyek dan tujuan } \\
\text { sektor/program }\end{array}$ \\
\hline Output Kegiatan : & $\begin{array}{l}\text { Tingkat output yang } \\
\text { diperlukan untuk mencapai } \\
\text { tujuan proyek: }\end{array}$ & $\begin{array}{l}\text { Untuk mengukur } \\
\text { capaian keberhasilan } \\
\text { dari output yang } \\
\text { dilaksanakan }\end{array}$ & $\begin{array}{l}\text { Asumsi hubungan antara } \\
\text { output dan tujuan proyek }\end{array}$ \\
\hline $\begin{array}{l}\text { Input : Kegiatan \& } \\
\text { berbagai sumberdaya }\end{array}$ & $\begin{array}{l}\text { Intensitas/pengeluaran untuk } \\
\text { setiap kegiatan dan } \\
\text { sumberdaya : }\end{array}$ & $\begin{array}{l}\text { Untuk mengukur } \\
\text { capaian keberhasilan } \\
\text { dari input yang } \\
\text { dilaksanakan }\end{array}$ & $\begin{array}{l}\text { Asumsi hubungan antara } \\
\text { input dan output }\end{array}$ \\
\hline
\end{tabular}

\section{HASIL DAN PEMBAHASAN}

Dalam penelitian ini analisis capaian perkembangan wilayah digunakan untuk mengevaluasi seberapa jauh capaian perkembangan wilayah yang dilakukan di Kecamatan Banda pasca penyelenggaraan Event Sail Banda. Evaluasi terhadap perkembangan wilayah di Kecamatan Banda menggunakan KKL atau kerangka kerja logis. Pada kerangka kerja logis yang digunakan untuk mengevaluasi, bagian outcome atau tujuan menggunakan tujuan dari penyelenggaraan Event Sail Banda yaitu menumbuhkan pusat - pusat perekonomian baru; meningkatkan kunjungan wisatawan; meningkatkan partisipasi swasta dalam pembangunan kesehjateraan rakyat berkelanjutan; serta meningkatkan kualitas dan kuantitas infrastruktur serta fasilitas umum lainnya. Berikut adalah kerangka kerja logis yang digunakan untuk mengevaluasi.

Table 2. Kerangka Kerja Logis Hasil Evaluasi (Hasil Olahan Pribadi, 2018)

\begin{tabular}{|c|c|c|c|}
\hline Ringkasan Naratif & Indikator Objektif & Alat Verifikasi & Asumsi Penting \\
\hline $\begin{array}{l}\text { Tujuan lebih besar yang } \\
\text { pencapaiannya akan } \\
\text { disumbang oleh proyek } \\
\text { 1. } \text { Tingkat pendapatan } \\
\text { masyarakat lokal } \\
\text { Kecamatan Banda } \\
\text { meningkat } \\
\text { 2. Kualitas SDM } \\
\text { masyarakat } \\
\text { Kecamatan Banda } \\
\text { meningkat }\end{array}$ & $\begin{array}{l}\text { 1. Adanya peningkatan } \\
\text { pendapatan masyarakat } \\
\text { dibandingkan dengan } \\
\text { sebelum pelaksanaan Event } \\
\text { Sail Banda } \\
\text { 2. Adanya peningkatan kualitas } \\
\text { SDM dibandingkan dengan } \\
\text { sebelum pelaksanaan Event } \\
\text { Sail Banda } \\
\text { 3. Semua desa di Kecamatan } \\
\text { Banda termasuk kategori } \\
\text { daerah maju dan } \\
\text { berkembang }\end{array}$ & $\begin{array}{ll}\text { 1. } & \text { Kuisioner } \\
\text { 2. } & \text { Observasi } \\
\text { Lapangan } \\
\text { 3. } \\
\text { 4. } \text { BPS } \\
\text { 5. Dinas } \\
\text { Pembera } \\
\text { Masyarakat dan } \\
\text { Desa }\end{array}$ & $\begin{array}{l}\text { Asumsi tentang nilai jangka } \\
\text { panjang proyek } \\
\text { Tujuan internal dari } \\
\text { penyelenggaraan Event Sail } \\
\text { Banda tercapai }\end{array}$ \\
\hline
\end{tabular}


3. Wilayah Kecamatan

Banda lebih

berkembang

\begin{tabular}{|c|c|c|c|c|}
\hline $\begin{array}{l}\text { Tujuan Proyek : } \\
\text { 1. } \text { Menumbuhkan pusat } \\
\text { - pusat perekonomian } \\
\text { baru sehingga } \\
\text { meningkatkan } \\
\text { pendapatan dan } \\
\text { kesehjateraan } \\
\text { masyarakat } \\
\text { Kecamatan Banda } \\
\text { 2. Meningkatkan } \\
\text { Kunjungan Wisatawan } \\
\text { 3eningkatkan } \\
\text { keterlibatan swasta } \\
\text { dalam pembangunan } \\
\text { kesehjateraan rakyat } \\
\text { yang berkelanjutan } \\
\text { seperti mendatangkan } \\
\text { investor } \\
\text { 4. Meningkatkan kualitas } \\
\text { dan kuantitas } \\
\text { infrastruktur serta } \\
\text { fasilitas lainnya }\end{array}$ & $\begin{array}{l}\text { Kondisi yang mencerminkan } \\
\text { tercapainya tujuan proyek : } \\
\text { 1. Peningkatan jumlah } \\
\text { wisatawan dibandingkan } \\
\text { dengan sebelum } \\
\text { pelaksanaan Event Sail } \\
\text { Banda } \\
\text { 2. Kondisi infrastruktur yang } \\
\text { membaik } \\
\text { 3. Pendapatan masyarakat } \\
\text { meningkat }\end{array}$ & $\begin{array}{l}3 . \\
4 . \\
5 .\end{array}$ & $\begin{array}{l}\text { Kuisioner } \\
\text { Observasi } \\
\text { Lapangan } \\
\text { Wawancara } \\
\text { BPS } \\
\text { Dinas Pariwisata } \\
\text { Kabupaten } \\
\text { Maluku Tengah } \\
\text { Monografi } \\
\text { Kecamatan Banda }\end{array}$ & $\begin{array}{l}\text { Asumsi hubungan antara } \\
\text { tujuan proyek dan tujuan } \\
\text { sektor/program } \\
\text { 1. Penyelenggaraan Event } \\
\text { Sail Banda yang sukses } \\
\text { 2. Pembangunan } \\
\text { infrastruktur dan } \\
\text { prasarana untuk } \\
\text { menunjang pariwisata } \\
\text { berjalan baik }\end{array}$ \\
\hline $\begin{array}{l}\text { Output Kegiatan : } \\
\text { Pelaksanaan Event Sail } \\
\text { Banda berjalan dengan } \\
\text { baik di Kecamatan Banda } \\
\text { dinilai dari : } \\
\text { 1. Masyarakat siap } \\
\text { menyambut Event Sail } \\
\text { Banda } \\
\text { 2. Infrastruktur jalan, } \\
\text { bandara, pelabuhan } \\
\text { diperbaiki } \\
\text { 3. Pelayanan } \\
\text { transportasi } \\
\text { meningkat } \\
\text { 4. Prasarana diperbaiki } \\
\text { 5. Perbaikan dan } \\
\text { peremajaan wisata } \\
\text { budaya dan sejarah } \\
\text { 6. Lingkungan dan lokasi } \\
\text { wisata alam menjadi } \\
\text { bersih } \\
\text { 7. Fasilitas penunjang } \\
\text { pariwisata seperti } \\
\text { rumah makan dan } \\
\text { penginapan dibangun }\end{array}$ & $\begin{array}{l}\text { Tingkat output yang } \\
\text { diperlukan untuk mencapai } \\
\text { tujuan proyek : } \\
\text { Keempat tujuan dari } \\
\text { pelaksanaan Event Sail } \\
\text { Indonesia tercapai }\end{array}$ & 1. & $\begin{array}{l}\text { Laporan } \\
\text { Pelaksanaan Event } \\
\text { Sail Banda dari } \\
\text { Dinas Pariwisata } \\
\text { Provinsi Maluku } \\
\text { Laporan } \\
\text { Pelaksanaan Event } \\
\text { Sail Banda dari } \\
\text { Kantor Kecamatan } \\
\text { Banda }\end{array}$ & $\begin{array}{l}\text { Asumsi hubungan antara } \\
\text { output dan tujuan proyek } \\
\text { 1. Tidak terjadi konflik } \\
\text { sosial antara } \\
\text { masyarakat dan } \\
\text { wisatawan yang } \\
\text { berkunjung } \\
\text { 2. Seluruh kegiatan } \\
\text { pembangunan untuk } \\
\text { menyambut Event Sail } \\
\text { Banda berjalan dengan } \\
\text { baik }\end{array}$ \\
\hline
\end{tabular}




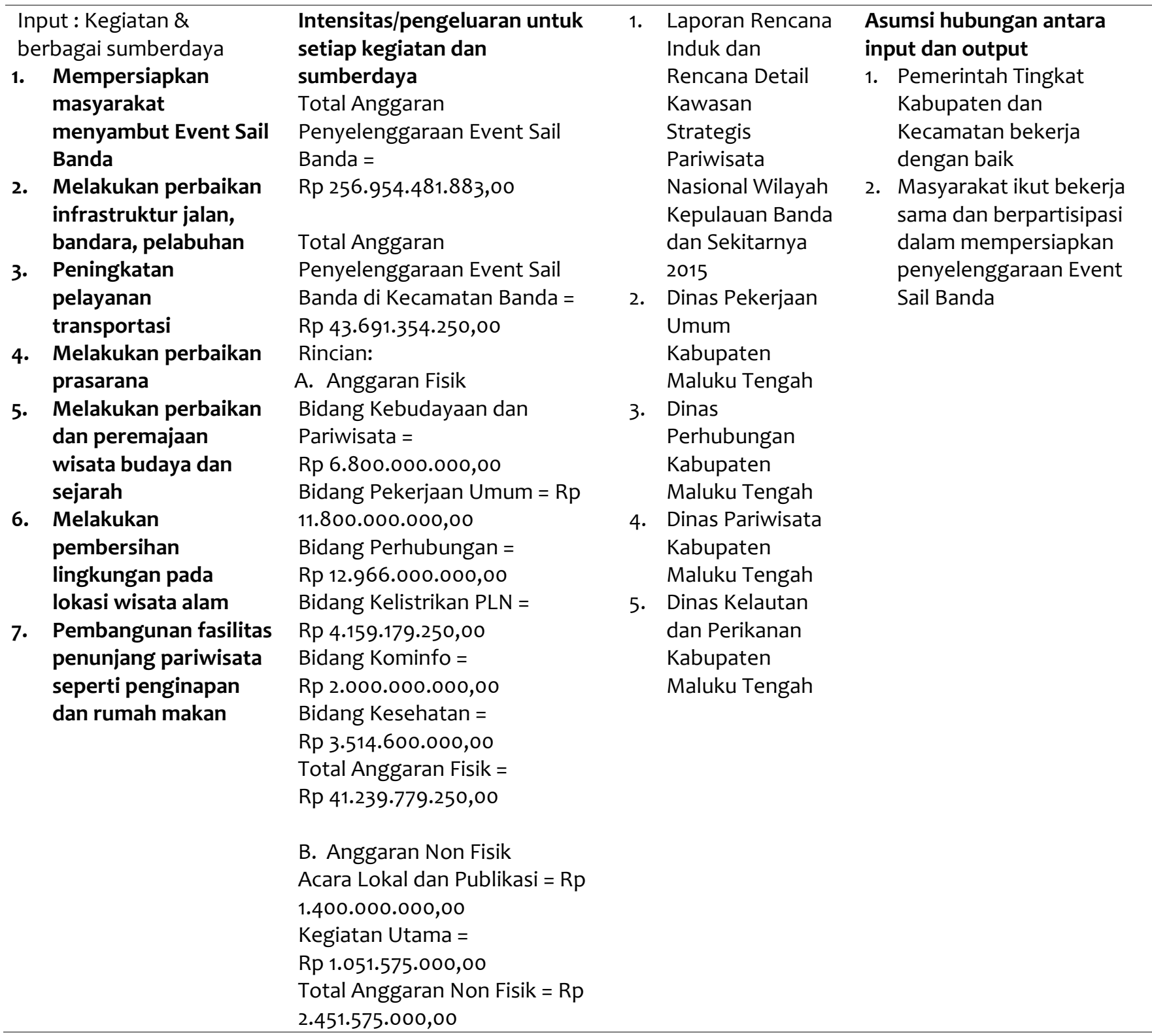

Berdasarkan hasil evaluasi dokumen dan pengamatan langsung di lapangan, pada bagian input : kegiatan \& berbagai sumberdaya ternyata tidak banyak persiapan yang dilakukan oleh Pemerintah tingkat Provinsi dan Kabupaten. Tidak banyak peningkatan dan perbaikan infrastruktur yang dilakukan oleh pemerintah sehingga tidak ada pembangunan yang maksimal. Selain infrastruktur, peningkatan dan perbaikan prasarana juga tidak dilakukan secara maksimal. Hanya peningkatan pelayanan penyediaan transportasi yang dilaksanakan. Sayangnya hal tersebut juga tidak bertahan lama setelah selesainya penyelenggaraan Event Sail Banda. Anggaran sebesar Rp 43.691.354.250,00 yang disediakan pun dirasa tidak dipergunakan secara maksimal dalam persiapan penyelenggaraan Event Sail Banda di Kecamatan Banda. Padahal masyarakat Kecamatan Banda sudah sangat siap untuk berpartisipasi dalam penyelenggaraan program Event Sail Banda. Berdasarkan hasil wawancara, salah seorang narasumber mengemukakan bahwa masyarakat secara sukarela ikut membantu persiapan acara seperti pembersihan lingkungan laut serta tempat - tempat wisata budaya dan sejarah. Pembangunan fasilitas penunjang pariwisata seperti penginapan dan rumah makan, sepenuhnya dipersiapkan oleh pihak swasta dan masyarakat setempat. 
Untuk bagian output kegiatan, sama halnya seperti yang sudah disampaikan sebelumnya, berdasarkan hasil evaluasi dokumen dan pengamatan langsung di lapangan ternyata tidak banyak persiapan yang dilakukan oleh Pemerintah tingkat Provinsi dan Kabupaten dalam mempersiapkan infrastruktur serta prasarana sehingga output yang diharapkan dari input kegiatan tersebut tidak tecapai. Output yang dapat dikatakan tercapai merupakan output yang input kegiatannya dilakukan oleh masyarakat serta swasta seperti wisata - wisata budaya dan sejarah di Kecamatan Banda diperbaiki dan dilakukan peremajaan, lingkungan dan lokasi wisata alam menjadi lebih bersih dan terawat, dan terbangunnya fasilitas penunjang pariwisata seperti rumah makan dan penginapan.

Kemudian pada bagian tujuan proyek berdasarkan hasil evaluasi dari pengamatan langsung di lapangan, sangat disayangkan bahwa dari keempat tujuan penyelenggaraan Event Sail Banda hanya satu tujuan yang dapat dicapai yaitu adanya peningkatan kunjungan wisatawan di Kecamatan Banda. Berdasarkan data yang diperoleh Dinas Pariwisata, Pemuda dan Olahraga UPTD Kecamatan Banda, jumlah wisatawan yang mengunjungi Kecamatan Banda terhitung dari tahun 2012 hingga 2017 mengalami peningkatan yang cukup signifikan. Walaupun jumlah wisatawan yang datang berkunjung ke Kecamatan Banda sempat menurun pada tahun 2013, pada tahun 2014 jumlah wisatawan kembali mengalami peningkatan secara terus menerus hingga tahun 2017. Berikut adalah tabel dan grafik jumlah dan tingkat wisatawan di Kecamatan Banda.

Tabel 3 Jumlah Kunjungan Wisatawan di Kecamatan Banda (Dinas Pariwisata, Pemuda dan Olahraga UPTD Kecamatan Banda, 2018)

\begin{tabular}{cc}
\hline Tahun & Jumlah Wisatawan \\
\hline 2012 & 1033 \\
\hline 2013 & 725 \\
\hline 2014 & 985 \\
\hline 2015 & 1779 \\
\hline 2016 & 1814 \\
\hline 2017 & 2187 \\
\hline
\end{tabular}

Sedangkan ketiga tujuannya lainnya yaitu menumbuhkan pusat - pusat perekonomian baru sehingga meningkatkan pendapatan dan kesehjateraan masyarakat, meningkatkan keterlibatan swasta dalam pembangunan kesehjateraan rakyat yang berkelanjutan seperti mendatangkan investor, meningkatkan kualitas dan kuantitas infrastruktur serta fasilitas lainnya tidak tercapai. Setelah penyelenggaraan Event Sail Banda 2010 tidak terlihat adanya pusat perekonomian baru di Kecamatan Banda. Pusat kegiatan dan perekonomian Kecamatan Banda hingga saat ini masih terpusat di Desa Nusantara yang berada di Pulau Neira. Untuk lebih jelasnya dapat dilihat pada peta berikut. 


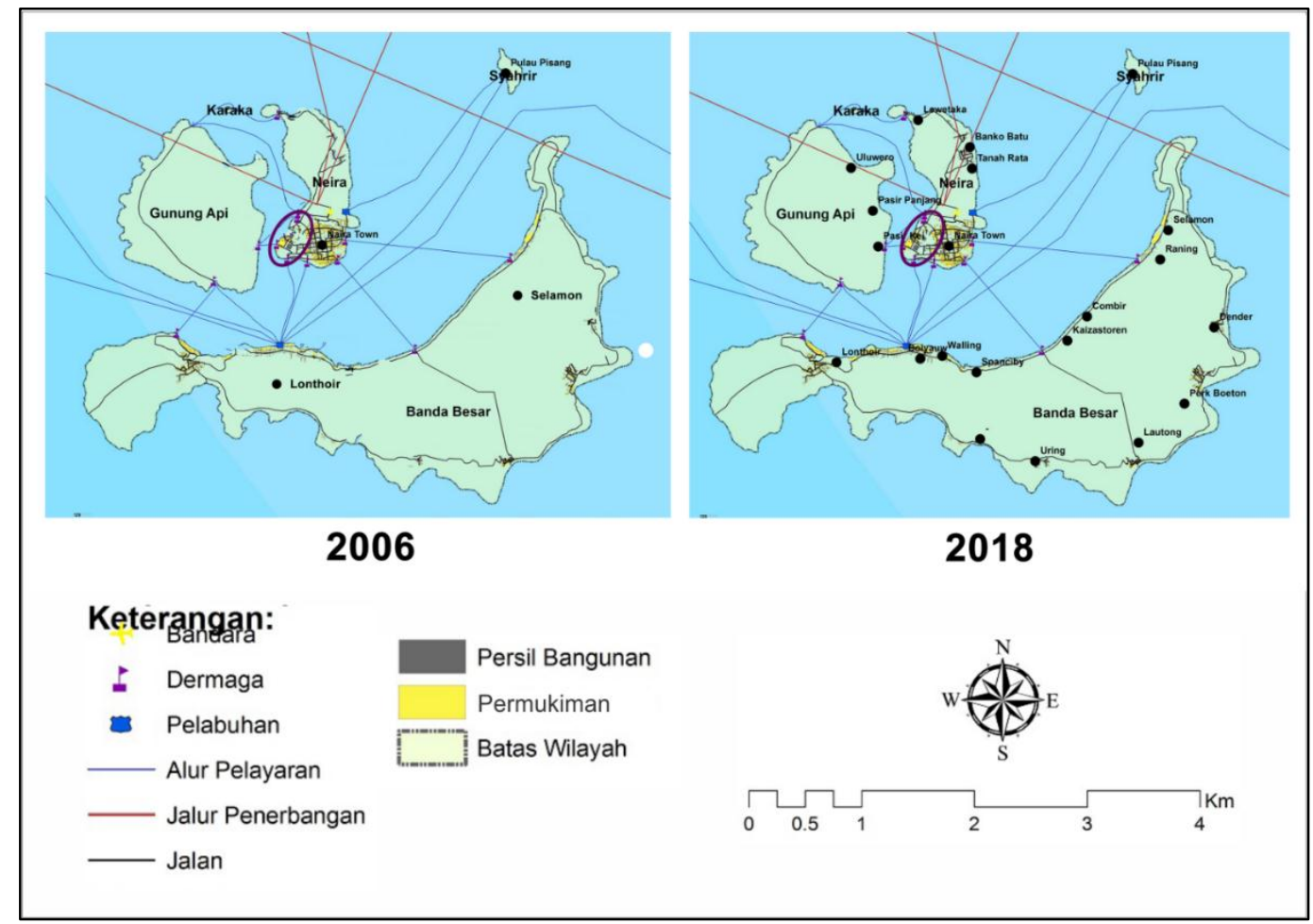

Gambar 2. Peta Pusat Ekonomi Kecamatan Banda (Hasil Olahan Pribadi, 2018)

Dapat dilihat dari peta diatas bahwa dari tahun 2006 sebelum penyelenggaraan Event Sail Banda hingga setelah penyelenggaraan Event Sail Banda pada tahun 2018, tidak ada penambahan pusat perekonomian baru di Kecamatan Banda. Walaupun muncul desa - desa baru hasil pemekaran, namun pusat perekonomian masih tetap terpusat di desa Nusantara yang ada di Pulau Naira. Begitu pula dengan keterlibatan pihak swasta atau investor dari luar. Sampai saat ini, pelayanan barang dan jasa di Kecamatan Banda hampir semuanya masih dilayani oleh masyarakat setempat. Hanya pada bidang penyediaan jasa yang sudah dilayani oleh pihak luar namun masih sedikit. Berdasarkan hasil wawancara, di Kecamatan Banda dari 18 penginapan yang tersedia hanya terdapat tiga penginapan yang dimiliki oleh pihak luar atau yang bukan masyarakat Kecamatan Banda. Ketiga penginapan tersebut adalah Hotel Maulana, Penginapan Nutmeg Tree, dan Penginapan Gamalama. Sisanya masih dilayani oleh masyarakat setempat. Untuk lebih jelasnya tentang kepemilikan penginapan di Kecamatan Banda, dapat dilihat pada tabel berikut.

Tabel 4 Kepemilikan Penginapan di Kecamatan Banda (Kecamatan Banda Dalam Angka 2017 dan Hasil Wawancara, 2018)

\begin{tabular}{clc}
\hline No & \multicolumn{1}{c}{ Nama Hotel } & Asal Pemilik \\
\hline $\mathbf{1}$ & Hotel Maulana & Luar Negeri \\
\hline $\mathbf{2}$ & Cilu Bintang Estate & Banda \\
\hline $\mathbf{3}$ & Penginapan Mutiara & Banda \\
\hline $\mathbf{4}$ & Penginapan Vita & Banda \\
\hline $\mathbf{5}$ & Penginapan Delfika & Banda \\
\hline $\mathbf{6}$ & Penginapan Bintang Laut & Banda \\
\hline $\mathbf{7}$ & Penginapan Gamalama & Ternate \\
\hline $\mathbf{8}$ & Penginapan Eldorado & Banda \\
\hline $\mathbf{9}$ & Home Stay Ardy & Banda \\
\hline
\end{tabular}




\begin{tabular}{lll}
\hline $\mathbf{1 0}$ & Home Stay Green Coconut & Banda \\
\hline $\mathbf{1 1}$ & Home Star Mawar & Banda \\
\hline $\mathbf{1 2}$ & Penginapan Wisata Rosmina & Banda \\
\hline $\mathbf{1 3}$ & Penginapan Pantai Nassau & Banda \\
\hline $\mathbf{1 4}$ & Home Stay Green Peach & Banda \\
\hline $\mathbf{1 5}$ & Hotel Laguna Inn & Banda \\
\hline $\mathbf{1 6}$ & Penginapan Nutmeg Tree & Masohi \\
\hline $\mathbf{1 7}$ & Penginapan Babussalam & Banda \\
\hline $\mathbf{1 8}$ & Penginapan Beatrix & Banda \\
\hline
\end{tabular}

Sedangkan untuk infrastruktur dan prasarana seperti yang sudah dijelaskan sebelumnya bahwa tidak banyak persiapan yang dilakukan oleh Pemerintah tingkat Provinsi dan Kabupaten dalam persiapan penyelenggaraan Event Sail Banda sehingga sampai saat ini belum banyak infrastruktur dan prasarana yang terbangun di Kecamatan Banda. Bahkan terdapat dua infrastruktur yang kualitasnya dianggap buruk oleh masyarakat yaitu jalan dan prasarana persampahan. Infrastruktur jalan yang kondisinya dianggap paling buruk terletak di Pulau Banda Besar. Akses jalan dari Desa Lonthoir menuju Desa Lautan begitu pula sebaliknya, serta akses jalan dari Desa Lautan menuju Desa Selamon begitu pula sebaliknya memiliki kondisi yang sangat buruk sehingga sangat sulit untuk diakses. Untuk lebih jelasnya mengenai lokasi dari infrastruktur jalan yang buruk dapat dilihat pada gambar peta berikut ini.

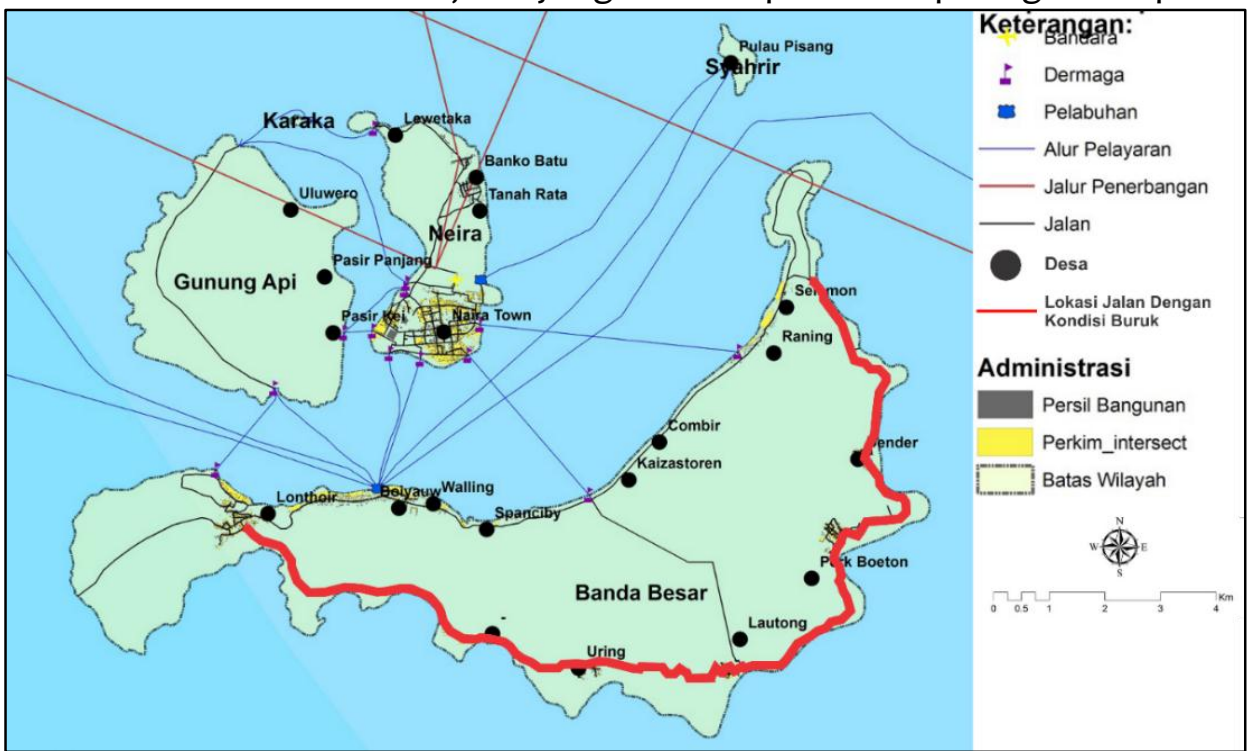

Gambar 3. Peta Lokasi Infrastruktur Jalan Yang Buruk (Hasil Olahan Pribadi, 2018)

Sedangkan prasarana persampahan yang ada dianggap belum cukup untuk melayani masyarakat sehingga masih terlihat penumpukan sampah di beberapa lokasi di Kecamatan Banda dan akhirnya mempengaruhi lingkungan sekitar. Penumpukan persampahan paling parah terjadi di beberapa lokasi seperti Desa Pulau Hatta, Desa Pulau Ay, Desa Selamon, Desa Combir-Kaisastoren dan Desa Rajawali. Hal ini tentunya menunjukan bahwa infrastruktur yang tersedia belum memiliki kualitas yang maksimal dan hampir sebagian besar masih berada pada tingkat sedang bahkan buruk. Tentunya diperlukan prioritas penanganan secepatnya untuk dapat meningkatkan kualitas infrastruktur yang dianggap masyarakat masih sedang 
bahkan buruk terutama seperti jalan dan prasarana persampahan. Untuk lebih jelasnya mengenai lokasi dari prasarana persampahan yang buruk dapat dilihat pada gambar peta berikut ini.

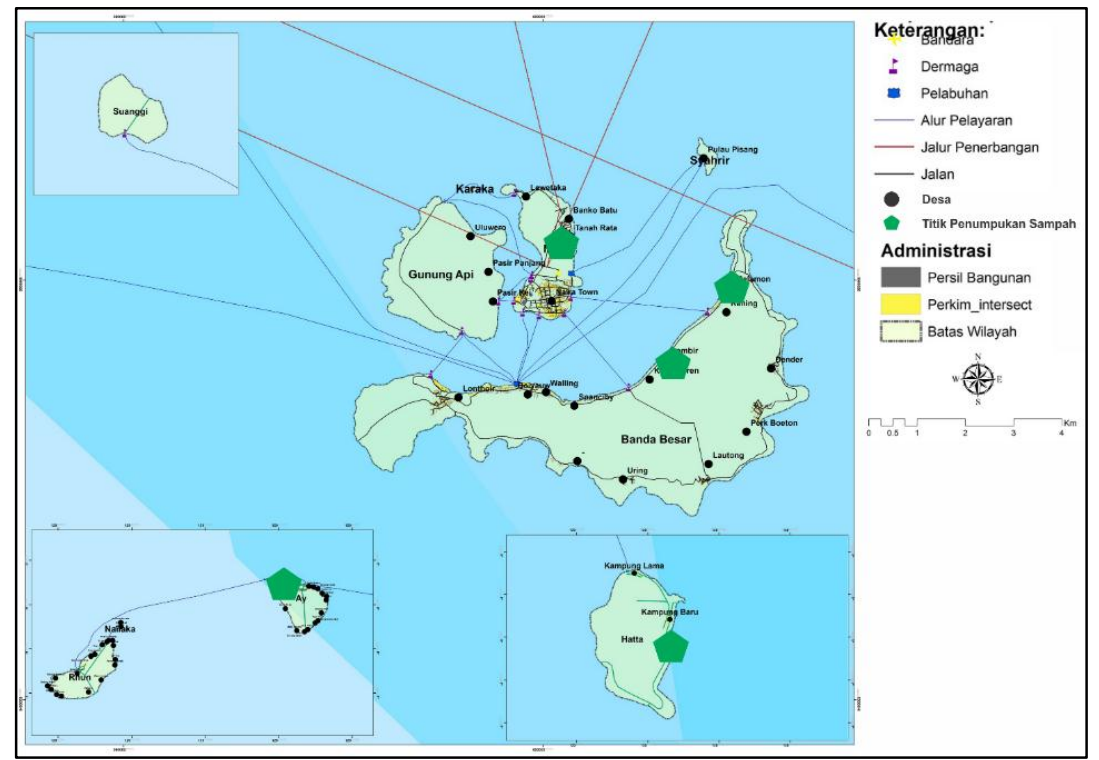

Gambar 4. Peta Lokasi Prasarana Persampahan Yang Buruk (Hasil Olahan Pribadi, 2018)

Kemudian untuk bagian tujuan lebih besar yang pencapaiannya akan disumbangkan oleh proyek, setelah dilakukan evaluasi dengan menggunakan ketiga indikator objektif tersebut hasil yang didapatkan adalah ketiga keuntungan yang dapat diperoleh dari penyelenggaraan Event Sail Banda gagal untuk dicapai. Apabila dilihat dari segi tingkat pendapatan dan juga kualitas sumber daya manusia tidak ada peningkatan yang terjadi pasca penyelenggaraan Event Sail Banda. Kemudian apabila dilihat dari segi penggolongan desa kedalam desa maju, berkembang, maupun tertinggal, Kecamatan Banda juga masih termasuk kedalam wilayah tertinggal walaupun sudah menyelenggarakan Event Sail Banda. Data dari Dinas Pemberdayaan Masyarakat dan Pembangunan Desa Provinsi Maluku juga menunjukan dari 18 desa yang ada di Kecamatan Banda hanya ada 3 desa yang dinyatakan maju, 5 desa dinyatakan berkembang, dan 10 desa sisanya dinyatakan tertinggal. Untuk lebih jelasnnya, berikut adalah daftar dari desa - desa yang termasuk kedalam kategori maju, berkembang, maupun tertinggal di Kecamatan Banda.

Tabel 5 Status Desa - Desa di Kecamatan Banda (Dinas Pemberdayaan Masyarakat dan Pembangunan Desa Provinsi Maluku, 2018)

\begin{tabular}{ccccc}
\hline \multirow{2}{*}{ No. } & Nama Desa & \multicolumn{3}{c}{ Status Desa } \\
\cline { 3 - 4 } & & Maju & Berkembang & Tertinggal \\
\hline $\mathbf{1}$ & Nusantara & $\mathrm{V}$ & \\
\hline $\mathbf{2}$ & Dwiwarna & $\mathrm{V}$ & & \\
\hline $\mathbf{3}$ & Merdeka & & $\checkmark$ & $\checkmark$ \\
\hline $\mathbf{4}$ & Rajawali & & & \\
\hline $\mathbf{5}$ & Kampung Baru & $\mathrm{V}$ & \\
\hline $\mathbf{6}$ & Pulau Hatta & & & $\mathrm{V}$ \\
\hline $\mathbf{7}$ & Selamon & & & \\
\hline $\mathbf{8}$ & Lonthoir & & $\checkmark$ & \\
\hline
\end{tabular}


Ambon, Royachansyah, Herwangi / Jurnal Pembangunan Wilayah dan Kota, Vol 15, No 1, 2019, 20-32

Doi: 10.14710/pwk.v15i1.21008

\begin{tabular}{cccc}
\hline $\mathbf{9}$ & Pulau Ay & $\mathrm{V}$ \\
\hline $\mathbf{1 0}$ & Pulau Rhun & $\mathrm{V}$ \\
\hline $\mathbf{1 1}$ & Tanah Rata & $\mathrm{V}$ & \\
\hline $\mathbf{1 2}$ & Waer & & \\
\hline $\mathbf{1 3}$ & Boiyauw & $\mathrm{V}$ & $\mathrm{V}$ \\
\hline $\mathbf{1 4}$ & Dender & $\mathrm{V}$ \\
\hline $\mathbf{1 5}$ & Lautang & $\mathrm{V}$ \\
\hline $\mathbf{1 6}$ & Uring Tutra & \\
\hline $\mathbf{1 7}$ & Walling Spanciby & $\mathrm{V}$ \\
\hline $\mathbf{1 8}$ & Combir Kaisastoren & \\
\hline
\end{tabular}

Menurut Muta'ali (2014), desa merupakan unit terkecil dan paling strategis dikarenakan dengan diketahuinya karakter dan sebaran dari desa tertinggal, hal itu dapat dijadikan sebagai alat untuk mengukur ketertinggalan kabupaten atau daerah. Dengan kata lain, semakin banyaknya desa tertinggal di dalam sebuah kabupaten, maka peluang daerah tersebut untuk dijadikan sebagai wilayah tertinggal semakin besar. Hal ini tentunya menunjukan bahwa walaupun sudah diselenggarakan, ternyata Event Sail Banda belum mampu untuk mendorong pembangunan wilayah di Kecamatan Banda sehingga masih dikategorikan sebagai wilayah tertinggal. Maka berdasarkan hasil evaluasi yang telah dilaksanakan, dapat disimpulkan bahwa penyelenggaraan Event Sail Banda di Kecamatan Banda tidak memberikan dampak yang signifikan terhadap peningkatan pendapatan dan kesehjahteraan masyarakat.

\section{KESIMPULAN}

Berdasarkan hasil evaluasi yang telah dilaksanakan, dapat disimpulkan bahwa penyelenggaraan Event Sail Banda di Kecamatan Banda tidak memberikan dampak yang signifikan terhadap peningkatan pendapatan dan kesehjahteraan masyarakat. Dari keempat tujuan penyelenggaraan Event Sail Banda hanya satu tujuan yang dapat dicapai yaitu adanya peningkatan kunjungan wisatawan di Kecamatan Banda. Sedangkan ketiga tujuannya lainnya yaitu menumbuhkan pusat - pusat perekonomian baru sehingga meningkatkan pendapatan dan kesehjateraan masyarakat, meningkatkan keterlibatan swasta dalam pembangunan kesehjateraan rakyat yang berkelanjutan seperti mendatangkan investor, meningkatkan kualitas dan kuantitas infrastruktur serta fasilitas lainnya tidak tercapai.

\section{PERNYATAAN RESMI}

Terima kasih kepada kedua orang tua saya yaitu Rusdi Ambon dan Diana Padang yang sudah selalu mendukung penulis sehingga dapat menyelesaikan penelitian ini.

\section{REFERENSI}

Allen, J., O`Toole, W., Harris, R. \& McDonnell, I. (2011). Festival \& Special Event Management. Australia.: John Wiley \& Sons.

Badan Pusat Statistik. (2017). Kecamatan Banda Dalam Angka. Badan Pusat Stastitik .: Maluku

Dinas Infokom Provinsi Maluku. (2010). Laporan Event Sail Banda. Dinas Infokom Provinsi Maluku .: Maluku 
Dinas Pariwisata dan Ekonomi Kreatif Provinsi Maluku. (2016). Laporan Rencana Induk dan Rencana Detail Kawasan Strategis Pariwisata Nasional Wilayah Kepulauan Banda dan Sekitarnya Tahun 2016. Dinas Pariwisata dan Ekonomi Kreatif Provinsi Maluku .: Maluku

Etiosa, Omoregie. (2012). The Impact of Event on Host Communities Case: The City of Pietarsaari. Tesis, Degree programme in Tourism, Central Ostrobothnia University of Applied Science.

Getz, Donald. (2007). Tourism Management Event Tourism: Defenition, Evolution Research. Tourism Management, 2008(29), 403-428. doi:10.1016/j.tourman.2007.07.017.

Gong, Qi. (2012). The Positive and Negative Economic Contributions of Mega-Sporting Events to Local Communities. Tesis, Master of Science Sport and Leisure Services Management William F. Harrah College of Hotel Administration, University of Nevada.

J, Spilane, James. (1987). Ekonomi Pariwisata, Sejarah dan Prospeknya. Yogyakarta .: PT. Kanisius

Kreag, G. (2001). The Impacts of Tourism. Minnesota .: Minnesota Sea Grant.

Lill, Gelda. (2015). The Impacts of Event on Local Community Case Study: The City of Tallinn. Tesis, Aalborg University.

Ling, Chen. (2006). Mega-events and infrastructure improvements----The Case of the Olympic Games in Beijing 2008. Tesis, Centre for East and South-East Asian Studies, Lund University.

Mahi, Ali Kabul. (2016). Pengembangan Wilayah. Jakarta .: Kencana

Mihajlovic, Iris dan Maja Vidak. (2017). The Importance of Local Events for Positioning of Tourist Destination. European Jurnal of Social Sciences Education and Research, 4(4), 228-239.

Moghaddam, Keivan Shabani dan Saifulla Shahabzade. (2015). Positive Effect of Sports Events : From Exaggeration to Reality. American Journal of Sport Science, 3(3), 52-56. doi: 10.11648/j.ajss.20150303.13. Muta'ali, Lutfi. (2014). Pengembangan Wilayah Tertinggal. Yogyakarta .: Badan Penerbit Fakultas Geografi Universitas Gadjah Mada

Nugroho, Iwan dan Rochman Dahuri. (2002). Pengembangan Wilayah Perspektif Ekonomi, Sosial, dan Lingkungan. Jakarta .: Pustaka LP3ES Indonesia

Pitana, I Gede dan I Ketut Surya Diarta. (2009). Pengantar Ilmu Pariwisata. Yogyakarta .: CV. Andi Offset Rustiadi, Ernan, Sunsun Saefulhakim dan Dyah R. Panuju. (2009). Perencanaan dan Pengembangan Wilayah. Jakarta .: Yayasan Obor Indonesia

Saputra, Heldi. (2016). Dampak Pelaksanaan Event Internasional Sail Indonesia Terhadap Perkembangan Wisata Bahari Indonesia. JOM Fisip, 3(2), 1-17.

Soebagyo. (2012). Strategi Pengembangan Pariwisata di Indonesia. Jurnal Liquidity, 1(2), 153-158.

Tanasale, Henry L.J. (2013). Mega Event Sail Banda 2010 Perangkat Pembangunan Kembali Kota Ambon Pasca Konflik. Tesis, Departemen Arsitektur dan Perencananaan, Universitas Gadjah Mada.

Zeil, Mansour Ezmail dan Mahin Ezmail Zeil. (2013). The Impacts of Tourism Industry on Host Community. European Journal of Tourism Hospitality and Research, 1(2), 12-21. 